\title{
PENGARUH PROFITABILITAS, LIKUIDITAS, DAN SOLVABILITAS TERHADAP OPINI AUDIT GOING CONCERN
}

\author{
NELY ANGGRAINI \\ Universitas Mataram \\ nely.anggraini@gmail.com \\ HERLINA PUSPARINI \\ Universitas Mataram \\ herlina.pusparini@unram.ac.id \\ ROBITH HUDAYA \\ Universitas Mataram \\ robith.hudaya@unram.ac.id
}

\section{Article History:}

Received: 10 Juni 2021

Revised: 30 Agustus 2021

Accepted: 1 September 2021

\begin{abstract}
This study aims to test the effect of profitability, liquidity, and solvency to the audit opinion going concern. Testing was conducted at 125 sample of the company service sector listed on the Indonesia Stock Exchange (IDX) in the 2015-2019. This type of research is associative research that aims to know the effect of profitability, liquidity, and solvency on audit opinion going concern. The type of research data is quantitative data with secondary data obtained from the company's financial statements accessed through the website official IDX and each sample company. Data processing techniques using logistic regression analysis methods with IBM SPSS software application 25. The result of this study indicate that profitability and liquidity have not significant effect on the audit opinion going concern, while but solvency has an significant effect on the audit opinion going concern. Research results can implications for corporate managers, auditors, investors, and creditors in making decisions and analyzing financial condition of the company that was threatened to get audit opinion going concern where it can establish the right policy for the condition.
\end{abstract}
Abstrak: Penelitian ini bertujuan untuk menguji pengaruh profitabilitas, likuiditas, dan solvabilitas terhadap opini audit going concern. Pengujian dilakukan pada 125 sampel perusahaan sektor jasa yang terdaftar di Bursa Efek Indonesia (BEI) pada tahun 2015 - 2019. Jenis penelitian ini adalah penelitian asosiatif yang bertujuan untuk mengetahui pengaruh antara profitabilitas, likuiditas, dan solvabilitas terhadap opini 


\section{DA}

Vol. 6, No. 1, Oktober 2021

audit going concern. Jenis data penelitian adalah data kuantitatif dengan data sekunder yang diperoleh dari laporan keuangan perusahaan yang diakses melalui website resmi Bursa Efek Indonesia (BEI) dan masingmasing perusahaan sampel. Teknik pengolahan data menggunakan metode analisis regresi logistik dengan aplikasi software IBM SPSS 25. Hasil penelitian ini menunjukkan bahwa profitabilitas dan likuiditas berpengaruh tidak signifikan terhadap opini audit going concern, sedangkan solvabilitas berpengaruh signifikan terhadap opini audit going concern. Hasil temuan penelitian dapat berimplikasi bagi manajer perusahaan, auditor, investor, serta kreditur dalam mengambil keputusan dan menganalisis kondisi keuangan perusahaan yang terancam mendapatkan opini audit going concern sehingga dapat menetapkan kebijakan yang tepat untuk kondisi tersebut

Keyword : Profitability, Liquidity, Solvency, and Audit Opinion Going Concern. Kata kunci : Profitabilitas, Likuiditas, Solvabilitas, Opini Audit Going Concern

\section{PENDAHULUAN}

Ketidakpastian kondisi ekonomi global dapat berdampak pada tingkat pertumbuhan ekonomi nasional. Hal tersebut terbukti, dengan menurunnya tingkat pertumbuhan ekonomi Indonesia tahun 2019 menjadi sebesar $5,02 \%$, padahal tahun sebelumnya telah berhasil meraih capaian tertinggi sejak tahun 2014, yaitu senilai 5,17\% (Badan Pusat Statistik, 2020). Penopang utama pertumbuhan ekonomi Indonesia tahun 2018 adalah dari sektor jasa, dengan peningkatan pesat sejak tahun 2012 dan tahun 2018 berhasil memberikan sumbangan sebesar 59\% dalam PDB Indonesia (Basri, 2019). Bank Indonesia menilai, menurunnya pertumbuhan ekonomi Indonesia tersebut dari segi global terjadi karena melemahnya ekonomi dunia akibat perang dagang antara Amerika Serikat dan China (Intan dan Zuraya, 2019). Peristiwa itu pun berdampak kepada produktivitas perusahaan nasional dalam bentuk efisiensi di berbagai bidang, baik dari segi biaya hingga jumlah tenaga kerja yang menyebabkan jumlah ekspor juga berkurang. Hal tersebut sesuai dengan pernyataan Kusuma (2019).yang menyatakan bahwa, "dampak perang dagang antara Amerika Serikat dan China yaitu, ekspor Indonesia tertekan, pasar modal terancam, serta penurunan pertumbuhan ekonomi".

Hakikatnya pertumbuhan suatu perusahaan akan selalu memiliki hubungan yang linear dan saling mempengaruhi dengan pertumbuhan ekonomi nasional maupun global. Keberlangsungan usaha (Going concern) suatu perusahaan menjadi hal penting yang dipertanyakan ketika terjadinya 
ketidakpastian ekonomi secara nasional maupun global. Standar Audit (SA) 570 menegaskan bahwa, tanggung jawab untuk menaksir apakah asumsi going concern masih valid atau tidak digunakan dalam menyusun laporan keuangan terletak di tangan manajemen (Institut Akuntan Publik Indonesia, 2012). Terdapat masalah keagenan antara manajemen dengan para stakeholders. Pihak-pihak yang berkepentingan (stakeholder) tersebut memiliki kepentingan yang berbeda dalam penggunaan laporan keuangan dengan manajer sebagai pengelola perusahaan dan penyaji laporan keuangan. Oleh karena itu, untuk mencegah manajer bertindak oportunistik dalam menyajikan laporan keuangan dibutuhkan peran auditor (Atikoh, 2017).

Peran auditor diperlukan untuk mencegah diterbitkannya laporan keuangan yang dapat menyesatkan para stakeholder dalam mengambil keputusan (Pradika, 2017). Auditor ekternal memberikan evaluasi atas laporan keuangan perusahaan yang dinyatakan melalui suatu opini audit. Opini audit yang diberikan auditor, menyatakan kewajaran penyajian laporan keuangan perusahaan yang disajikan manajer (Agoes, 2011). Auditor dapat memberikan opini audit dengan modifikasi mengenai going concern, untuk menyatakan keraguan terhadap keberlangsungan perusahaan auditee (IAPI, 2012). Opini audit going concern berkaitan dengan analisis yang dilakukan auditor, dalam menilai ketepatan asumsi going concern yang digunakan manajer dalam menyusun laporan keuangan.

Menurut Chen dan Church (1996 dalam Wibisono, 2019), "ketika kondisi ekonomi merupakan sesuatu yang tidak pasti, para investor dan stakeholders lainnya mengharapkan auditor memberikan peringatan awal akan kegagalan keuangan perusahaan". Pengguna informasi keuangan mengharapkan auditor untuk menginformasikan tentang situasi nyata dan pandangannya tentang perusahaan secara adil dan benar (Gallizo dan Saladrigues, 2016).

Meskipun evaluasi atas kondisi kesehatan keuangan perusahaan bukan tujuan dari suatu proses audit, tetapi auditor memiliki tanggung jawab dalam mengevaluasi apakah perusahaan auditee memiliki kecenderungan untuk tetap bertahan melangsungkan usahanya dalam jangka panjang (Junaidi dan Nurdiono, 2016). Saat menerbitkan opini audit going concern, auditor harus menganalisis berbagai indikator yang mempengaruhi kegagalan perusahaan dalam mempertahankan kelangsungan hidupnya meliputi, kondisi ekonomi secara umum, kondisi industri, dan kondisi entitas (Purba, 2016).

Kondisi entitas menjadi hal pertama yang perlu dianalisis auditor sebagai pertimbangan pemberian opini. Dalam memberikan suatu opini going concern (keberlangsungan usaha) meninjau dari kondisi entitas, auditor melakukan analisis terhadap faktor keuangan dan faktor non keuangan yang mempengaruhi pemberian opini going concern 


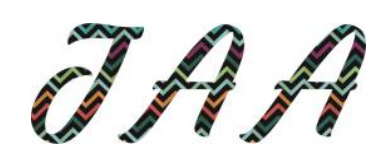

Vol. 6, No. 1, Oktober 2021

(keberlangsungan usaha) (Junaidi dan Nurdiono, 2016). Faktor keuangan bersumber dari laporan keuangan, yang dapat dianalisis dengan beberapa metode seperti, analisis rasio keuangan, analisis fluktuasi saldo, dan financial distress model (Purba, 2016). Sedangkan, faktor non keuangan yang mempengaruhi pemberian opini audit going concern meliputi, mitigating evidence, disclosure, risiko, reputasi auditor, tenur auditor, dan ukuran perusahaan (Junaidi dan Nurdiono, 2016).

Penelitian ini berfokus pada faktor keuangan yang dianalisis menggunakan rasio keuangan. Faktor keuangan bersumber dari kondisi internal perusahaan itu sendiri dan secara mendasar menggambarkan bagaimana perusahaan menjalankan operasional usahanya, sehingga bersifat mempengaruhi secara langsung pemberian opini audit going concern. Hal tersebut didukung oleh pernyataan Purba (2016) yang menyatakan bahwa kondisi keuangan perusahaan merupakan kunci utama dalam melihat apakah perusahaan akan mampu mempertahankan kelangsungan usahanya atau tidak pada masa yang akan datang. Analisis rasio merupakan salah satu alat yang paling populer dan banyak digunakan untuk analisis keuangan.

Beberapa jenis rasio keuangan untuk mengetahui dan menganalisis going concern suatu entitas antara lain seperti, rasio likuiditas, rasio solvabilitas, rasio aktivitas, dan rasio profitabilitas. Purba (2016) mengungkapkan bahwa, "berdasarkan pernyataan kesimpulan yang diambil dari penelitian yang pernah dilakukan oleh para ahli corporate failure, rasio keuangan yang paling sering digunakan dalam memprediksi kepailitian yaitu jenis rasio likuiditas, solvabilitas, dan profitabilitas. Pemilihan fokus penelitian pada analisis rasio-rasio keuangan tersebut, sebagai faktor keuangan yang mempengaruhi pemberian opini going concern juga dilatar belakangi oleh studi pendahuluan berdasarkan peristiwa-peristiwa yang telah terjadi di masa lampau, di mana faktor seperti profitabilitas, likuiditas, dan solvabilitas adalah yang paling banyak disinggung menjadi penyebab kegagalan usaha suatu entitas, sehingga mempengaruhi pula pertimbangan auditor dalam pemberian opini audit going concern.

Pengukuran rasio profitabilitas dengan return on equity (ROE) diperlukan untuk mengetahui efisiensi penggunaan modal oleh suatu entitas dalam memperoleh laba, yang kemudian dari hasil tersebut dapat dianalisis bagaimana dampaknya terhadap penerimaan opini audit going concern (Kasmir, 2019). Beberapa penelitian terdahulu menyimpulkan bahwa profitabilitas berpengaruh signifikan terhadap opini audit going concern yaitu, penelitian dari Tryansyah dan Khairunnisa (2019) dan Kurbani et al., (2019). Namun, penelitian yang dilakukan oleh Purba dan Nazir (2019) dan Nugroho et al. (2018) menunjukkan hasil yang bertolak belakang bahwa, profitabilitas tidak berpengaruh siginifikan terhadap opini audit going concern. Selain rasio profitabilitas, pengukuran terhadap rasio likuiditas 
turut pula diperlukan untuk mengetahui bagaimana dampaknya terhadap opini audit going concern.

Adapun pengukuran rasio likuiditas dalam penelitian ini dengan cash ratio, akan menunjukkan seberapa besar ketersediaan uang kas yang dimiliki perusahaan untuk membayar utang. Penelitian dari Kurbani et al., (2019) menunjukkan hasil bahwa likuiditas berpengaruh terhadap opini audit going concern. Namun, hasil penelitian dari Haryanto dan Sudarno (2019) memperoleh hasil bahwa likuiditas tidak berpengaruh signifikan terhadap opini audit going concern. Hasil penelitian tersebut, didukung oleh hasil penelitian dari Nugroho et al. (2018) dan Anita (2017). Selain rasio profitabilitas dan likuiditas, pengukuran terhadap rasio solvabilitas juga dipandang penting untuk analisis keterkaitannya dengan penerimaan opini audit going concern.

Dengan pengukuran solvabilitas menggunakan debt to equity ratio, dapat diketahui jumlah dana yang disediakan kreditur dengan pemilik perusahaan. Hasil penelitian dari Purba dan Nazir (2019) membuktikan bahwa, solvabilitas berpengaruh signifikan terhadap opini audit going concern. Penelitian dari Haryanto dan Sudarno (2019) serta Rahman dan Ahmad (2018) menunjukkan hasil yang sama dengan penelitian tersebut, akan tetapi penelitian dari Jalil (2019) justru menunjukkan bahwa solvabilitas tidak berpengaruh signifikan terhadap opini audit going concern.

Melalui penelitian ini, dapat ditemukan bukti empiris mengenai faktor-faktor keuangan yang mempengaruhi pemberian opini audit going concern, sehingga dapat menambah wawasan dan ilmu pengetahuan tentang opini audit going concern, serta menjadi tambahan literatur referensi untuk penelitian-penelitian selanjutnya. Secara praktis, hasil penelitian dapat dimanfaatkan oleh para auditor sebagai bahan pertimbangan untuk meninjau secara lebih teliti terkait dengan faktor-faktor yang mempengaruhi pemberian opini audit going concern, sehingga dengan pertimbangan analisis yang matang dan hati-hati dapat memberikan opini audit going concern yang tepat pada perusahaan, yang dari segi keuangan memiliki indikasi keberlangsungan usaha diragukan. Selain itu, hasil penelitian dapat juga dijadikan acuan oleh manajer dalam mengelola perusahaan dengan lebih baik, sehingga dapat mencegah perusahaan mendapatkan opini audit going concern dari auditor. Penelitian ini juga dapat bermanfaat sebagai acuan bagi investor dan kreditur dalam menilai keberlangsungan usaha dari suatu perusahaan, sehingga dapat menganalisis lebih mendalam terkait dengan pengambilan keputusan untuk penanaman investasi dan pemberian kredit kepada perusahaan. 


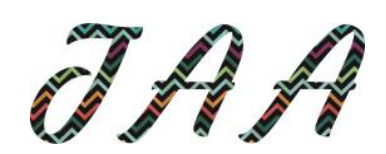

Vol. 6, No. 1, Oktober 2021

\section{TELAAH LITERATUR DAN PENGEMBANGAN HIPOTESIS}

\section{Pengaruh Profitabilitas Terhadap Opini Audit Going Concern}

Berangkat dari Agency theory dan teori pemangku kepentingan atau stakeholder theory yang berusaha mengakomodir berbagai kepentingan dalam sebuah entitas, profitabilitas masih merupakan unsur penting dalam menilai berhasil atau tidaknya suatu entitas mencapai tujuan usaha. Kasmir (2019) mengatakan bahwa, "tujuan akhir yang ingin dicapai suatu perusahaan yang terpenting adalah memperoleh laba atau keuntungan yang maksimal". Hal tersebut sejalan dengan pendapat dari Rohim (2018) yang mengatakan bahwa, "rasio profitabilitas sangat penting bagi perusahaan dikarenakan dapat menggambarkan kelangsungan hidupnya (going concern)".

Suatu perusahaan harus ada dalam keadaan yang menguntungkan, untuk dapat menarik modal dari pihak luar sehingga usaha dapat terus berkembang pesat. Sesuai dengan teori stakeholder yang menyatakan bahwa eksistensi perusahaan memerlukan dukungan stakeholder atau pihak luar dan manajemen harus dapat memperoleh laba untuk para stakeholder. Manajer dituntut untuk dapat membangun kerangka kerja yang responsif terhadap berbagai masalah yang dihadapi, yaitu perubahan lingkungan. Dalam berbagai situasi ketidakpastian lingkungan usaha, manajer harus dapat berfikir kreatif dan inovatif untuk dapat selalu mencari solusi agar menghasilkan laba bagi perusahaan.

Dalam teori hubungan keagenan juga dijelaskan bahwa profitabilitas merupakan suatu hal yang menjadi tujuan dasar bersama dari kontrak antara agent dan principal. Manajer sebagai agent bertanggung jawab untuk mengoptimalkan keuntungan (profit) para pemilik (principa). Namun demikian, manajer juga menginginkan untuk selalu memperoleh bonus (kompensasi) sesuai dengan kontrak atas kinerjanya. Principal menginginkan perusahaan dikelola dengan sebaik-baiknya oleh agent sesuai dengan aturan yang berlaku sehingga bisa menghasilkan laba, sedangkan agent menginginkan para stakeholder merasa puas dengan kinerjanya selama mengelola perusahaan yang ditunjukkan dengan meningkatnya laba (profit) dari periode ke periode untuk memperoleh reward atas prestasinya, meskipun untuk mencapai hal tersebut pihak manajemen terkadang menghalalkan segala cara (Arifah et al., 2012).

Adanya pengaruh profitabilitas terhadap penerimaan opini audit going concern yang mengindikasikan keraguan auditor akan keberlangsungan usaha suatu entitas, didukung dari hasil penelitian yang dilakukan oleh Rahman dan Ahmad (2018), Tryansyah dan Khairunnisa (2019), Bayudi dan Wirawati (2017), Kurbani et al., (2019), serta Haryanto dan Sudarno (2019). Namun hasil penelitian tersebut justru bertolak belakang dengan penelitian dari Anita (2017), Nugroho et al., (2018), dan Purba dan Nazir (2019). 
Berdasarkan hal tersebut maka peneliti merasa perlu melakukan pengujian kembali mengenai pengaruh profitabilitas terhadap opini audit going concern, untuk memperkuat pendapat-pendapat dari penelitian sebelumnya. Oleh karena itu, rumusan hipotesis yang diajukan dalam penelitian ini adalah:

\section{$H_{1}$ : Profitabilitas berpengaruh signifikan terhadap opini audit going concern}

\section{Pengaruh Likuiditas Terhadap Opini Audit Going Concern}

Ramadhan (2020) berpendapat bahwa, "likuiditas merupakan salah satu pedoman penting bagi navigasi dan keberlangsungan sebuah perusahaan". Tingkat likuiditas dapat menjadi pedoman untuk evaluasi kinerja, efisiensi keuangan, dan menganalisa kondisi keuangan perusahaan. Indrawati (2011) mengatakan bahwa, "perusahaan harus dapat mempertahankan likuiditasnya untuk tetap mendapatkan dukungan dari para stakeholder (pihak-pihak yang berkepentingan). Masalah likuiditas dapat mengganggu hubungan baik antara perusahaan dengan para kreditur maupun distributor, bahkan dalam jangka panjang juga berdampak kepada pelanggan (konsumen) yang tidak percaya lagi kepada perusahaan. Padahal kepercayaan merupakan modal utama perusahaan dalam mencapai target yang telah ditetapkan (Kasmir, 2019).

Teori stakeholder bertujuan untuk membantu manajer agar dapat melakukan pengelolaan perusahaan dengan lebih efektif, sehingga dapat mempertahankan kelangsungan hidupnya yang ditunjukkan dengan kemampuan yang baik dalam memenuhi semua kewajiban lancarnya (likuiditas perusahaan). Hasil penelitian dari Kurbani et al., (2019) menyatakan likuiditas berpengaruh terhadap terhadap opini audit going concern, sementara penelitian dari beberapa peneliti lainnya justru mengatakan bahwa likuiditas tidak berpengaruh terhadap opini audit going concern, diantaranya seperti penelitian yang dilakukan oleh Rahman dan Ahmad (2018), Purba dan Nazir (2019), Bayudi dan Wirawati (2017), Yaqin dan Sari (2015), Haryanto dan Sudarno (2019), Nugroho et al. (2018), serta Anita (2017).

Berdasarkan hal tersebut maka peneliti tertarik untuk menguji kembali pengaruh dari likuiditas terhadap opini audit going concern sehingga memperkuat hasil dari penelitian sebelumnya dengan rumusan hipotesis penelitian yaitu:

\section{$\mathrm{H}_{2}$ : Likuiditas berpengaruh signifikan terhadap opini audit going concern}

\section{Pengaruh Solvabilitas Terhadap Opini Audit Going Concern}

Dalam membangun sebuah perusahaan, hal pertama yang diperhatikan adalah dana, baik dana awal pembangunan maupun dana pengembangan perusahaan. Dana atau modal juga penting untuk 


\section{DA}

Vol. 6, No. 1, Oktober 2021

keberlangsungan hidup suatu perusahaan, dan untuk memperolehnya utang menjadi salah satu jalan yang di tempuh. Solvabilitas menjadi alat untuk mengukur kemampuan perusahaan dalam mengembalikan utang atau pinjaman yang diberikan oleh pihak ketiga, baik itu utang jangka pendek maupun utang jangka panjang (Aprilia,2019).

Dalam praktiknya, perusahaan yang memiliki rasio solvabilitas yang tinggi dapat menimbulkan kerugian yang lebih besar, tetapi ada kesempatan juga mendapatkan laba yang lebih besar (Kasmir, 2019). Oleh karena itu, manajer keuangan harus dapat mengelola solvabilitas perusahaan dengan baik sehingga mampu menyeimbangkan pengembalian yang tinggi dengan risiko yang dihadapi demi menjaga perusahaan dalam kondisi going concern dan tidak mendapatkan opini audit going concern

Auditor pun harus dapat memberikan pertimbangan yang tepat dalam menentukan pemberian opini audit terhadap suatu perusahaan, dengan memperhatikan kewajaran atas nilai-nilai yang dilaporkan dalam laporan keuangan, serta menganalisis bagaimana nilai yang disajikan salah satunya dengan menganalisis rasio solvabilitas perusahaan. Berdasarkan teori atribusi, auditor harus dapat berperilaku secara independen dan konsisten saat menafsirkan dengan tepat laporan entitas yang diaudit. Berkaitan dengan solvabilitas perusahaan menjadi hal penting yang harus ditelaah mendalam oleh auditor karena berhubungan dengan kemampuan perusahaan memenuhi kewajiban jangka panjangnya, sehingga auditor dapat memastikan keberlangsungan usaha suatu entitas tersebut di masa yang akan datang dengan kondisi solvabilitas yang dimiliki. Beberapa hasil penelitian dari peneliti sebelumnya, seperti Rahman dan Ahmad (2018), Purba dan Nazir (2019), Haryanto dan Sudarno (2019), Nugroho et al., (2018), serta Anita (2017) memberikan hasil bahwa solvabilitas berpengaruh terhadap opini audit going concern, sedangkan penelitian dari peneliti lainnya justru memberikan hasil bahwa solvabilitas tidak berpengaruh terhadap opini audit going concern ,yaitu penelitian dari Tryansyah dan Khairunnisa (2019) dan juga Jalil (2019).

Berdasarkan ketidakkonsistenan hasil yang ditunjukkan beberapa penelitian terdahulu maka peneliti merasa perlu untuk menguji kembali pengaruh solvabilitas terhadap opini audit going concern untuk memperkuat hasil dari penelitian-penelitian sebelumnya dengan rumusan hipotesis yang akan diuji yaitu:

\section{$\mathrm{H}_{3}$ : Solvabilitas berpengaruh signifikan terhadap opini audit going concern}

\section{METODE PENELITIAN}

Jenis penelitian yang digunakan dalam penelitian ini yaitu, jenis penelitian asosiatif dengan pendekatan kuantitatif. Penelitian ini dilakukan pada perusahaan sektor jasa yang terdaftar di Bursa Efek Indonesia (BEI) 
tahun 2015-2019. Metode pengambilan sampel dilakukan secara non probabilitas (non random) berupa purposive sampling. Pengambilan sampel bertujuan (purposive sampling) ditentukan dengan memperhatian kriteriakriteria pengambilan sampel sebagai berikut:

Tabel 3.1

Kriteria Penarikan Sampel

\begin{tabular}{llc}
\hline No & \multicolumn{1}{c}{ Kriteria } & Jumlah \\
\hline 1 & $\begin{array}{l}\text { Perusahaan sektor jasa yang terdaftar di Bursa Efek } \\
\text { Indonesia pada tahun pengamatan penelitian yaitu } \\
\text { tahun 2015-2019. }\end{array}$ & 218
\end{tabular}

2 Perusahaan sektor jasa yang tidak listing (tercatat) di Bursa Efek Indonesia mulai dari tahun 2015 - 2019.

3 Perusahaan sektor jasa yang tidak menerbitkan laporan keuangan tahunan lengkap atau tidak dapat diakses selama periode pengamatan tahun 2015-2019.

$4 \quad$ Perusahaan sektor jasa yang tidak menyediakan laporan auditor independen secara lengkap selama periode pengamatan tahun 2015-2019.

5 Perusahaan sektor jasa yang tidak menyajikan laporan keuangan dalam satuan mata uang Rupiah.

\begin{tabular}{lc}
\hline Jumlah Perusahaan Sampel Penelitian & 125 \\
\hline Tahun Pengamatan & 5 \\
\hline Total Sampel Selama Periode Pengamatan & 625
\end{tabular}

Sumber: idx.co.id

\section{Variabel Penelitian}

Variabel Independen

Variabel independen dalam penelitian ini meliputi:

\section{Profitabilitas $\left(\mathbf{X}_{\mathbf{1}}\right)$}

Profitabilitas diukur dengan menggunakan rasio hasil pengembalian ekuitas atau return on equity, yang menunjukkan efisiensi penggunaan modal sendiri. Semakin tinggi rasio profitabilitas maka semakin baik, yang artinya posisi pemilik perusahaan semakin kuat (Kasmir, 2019). Rumus menghitung ROE yaitu sebagai berikut:

$$
\text { Return On Equity }(\mathrm{ROE})=\frac{\text { Earning After Interest and Tax }}{\text { Equity }} \times 100 \%
$$




\section{DA}

Vol. 6, No. 1, Oktober 2021

Sumber : Kasmir, 2019

\section{Likuiditas ( $\left.\mathbf{X}_{2}\right)$}

Likuiditas dalam penelitian ini diukur menggunakan rasio kas atau cash ratio. Rasio ini mengukur likuiditas dengan melihat seberapa besar uang kas yang tersedia untuk membayar utang (Kasmir, 2019). Rasio kas yang baik adalah rasio kas yang nilainya di atas 1 (satu) atau rasio kas yang memiliki kenaikan tren. Rasio kas di atas 1 berarti perusahaan memiliki kas yang lebih besar dibandingkan utang lancarnya, sehingga dapat disimpulkan dengan kas dan setara kas yang dimiliki, perusahaan dapat melunasi utang jangka pendeknya dan aman dari risiko likuidasi (Heze, 2018). Rumus untuk menghitung rasio kas yaitu:

$$
\text { Cash Ratio }=\frac{\text { Kas + Bank }}{\text { Current Liabilities }} \times 100 \%
$$

Sumber : Kasmir, 2019

\section{Solvabilitas $\left(\mathbf{X}_{3}\right)$}

Pengukuran solvabilitas dalam penelitian ini, menggunakan rasio debt to equity ratio melalui perbandingan antara nilai utang dengan ekuitas. Dalam perbandingan tersebut, nilai utang yang digunakan adalah secara keseluruhan yaitu utang jangka pendek ditambah dengan utang jangka panjang. Bagi perusahaan, semakin besar rasio ini maka akan semakin baik. Sebaliknya, semakin rendah rasio ini menunjukkan semakin tinggi tingkat pendanaan yang disediakan pemilik dan semakin besar batas pengamanan bagi peminjam dana (kreditur), jika terjadi kerugian atau penyusutan terhadap nilai aktiva (Kasmir, 2019) Rumus untuk menghitung rasio ini sebagai berikut:

$$
\begin{gathered}
\text { Debt to Equity Ratio (DER) }=\frac{\text { Total Utang (Debt) }}{\text { Ekuitas (Equity) }} \times 100 \% \\
\text { Sumber : Kasmir, } 2019
\end{gathered}
$$

\section{Variabel Dependen}

Variabel dependen dalam penelitian ini yaitu, opini audit going concern. Pengukuran opini audit going concern dalam penelitian ini menggunakan variabel dummy. Pengukuran dengan variabel dummy adalah teknik pengukuran atas variabel yang berskala ukuran non metrik atau kategori, dengan cara pemberian kode dummy yang umumnya menggunakan kategori yang dinyatakan dengan angka 1 atau 0. Kelompok yang diberi nilai dummy 0 (nol) disebut excluded group, sedangkan kelompok yang diberi nilai dummy 1 (satu) disebut included group (Mirer, 1990 dalam Ghozali, 2018). Oleh karena itu, dalam pengukuran variabel $Y$ pada penelitian ini menggunakan variabel dummy, diklasifikasikan menjadi dua kategori yaitu: 
1. Perusahaan yang mendapatkan opini audit wajar tanpa pengecualian dengan bahasa penjelasan, pendapat wajar dengan pengecualian, pendapat tidak wajar, dan pernyataan tidak memberikan pendapat, termasuk dalam kategori perusahaan yang memperoleh opini audit going concern dan diberikan kode dummy 1.

2. Perusahaan yang mendapatkan opini audit wajar tanpa pengecualian, termasuk dalam kategori memperoleh opini audit non going concern dan diberikan kode dummy 0.

\section{Prosedur Analisis Data}

\section{Analisis Statistik Deskriptif}

Prosedur analisis statistik deskriptif melalui uji statistik deskriptif dilakukan untuk memberikan gambaran nilai rata-rata (mean), standar deviasi, varian, maksimum, minimum, sum, range, kurtosis, dan swekness (kemencengan distribusi) dari setiap variabel yang diteliti meliputi variabel profitabilitas $\left(\mathrm{X}_{1}\right)$, likuiditas $\left(\mathrm{X}_{2}\right)$, solvabilitas $\left(\mathrm{X}_{3}\right)$, dan opini audit going concern $(\mathrm{Y})$.

\section{Analisis Uji Asumsi Klasik}

Uji asumsi klasik merupakan asumsi bahwa setiap variabel dan semua kombinasi linear dari variabel berdistribusi normal. Namun, asumsi tersebut tidak berlaku sepenuhnya pada uji analisis regresi logistik. Menurut Gregory dan Bader (2018) dalam artikel yang berjudul "Logistic and Linear Regression Assumptions: Violation Recognition and Control", menjelaskan beberapa asumsi yang berlaku untuk regresi logistik adalah sebagai berikut:

a. Asumsi struktur hasil yang sesuai

b. Asumsi independensi observasi

c. Asumsi tidak ada multikolonieritas

d. Asumsi linearitas variabel independen dan ganjil log

e. Asumsi ukuran sampel yang besar

Berdasarkan asumsi-asumsi tersebut, maka dapat disimpulkan uji asumsi klasik yang diperlukan dalam penelitian ini hanya uji multikolonieritas.

\section{Analisis Regresi Logistik (Logistic Regression)}

Penelitian ini menggunakan tipe analisis regresi logistik biner karena, variabel terikat berbentuk non-metrik (kategori) atau data kualitatif yang diberi kode dummy (dikuantitatifkan) menjadi dua kategori yaitu, perusahaan yang menerima opini audit going concern dan perusahaan yang menerima opini audit non going concern (Ghozali, 2018:325).

Model regresi logistik yang digunakan untuk menguji hipotesis adalah sebagai berikut: 


$$
\operatorname{Ln} \frac{\mathbf{Y}}{\mathbf{1}-\mathbf{Y}}=\underset{\text { Sumber : Ghozali, } 2018}{=\boldsymbol{\beta}_{\mathbf{0}}+\boldsymbol{\beta}_{\mathbf{1}} \boldsymbol{X}_{\mathbf{1}}+\dot{\boldsymbol{\beta}}_{2} \boldsymbol{X}_{\mathbf{2}}+\boldsymbol{\beta}_{3} \boldsymbol{X}_{\mathbf{3}}+\boldsymbol{\varepsilon}}
$$

Keterangan:

$\operatorname{Ln} \frac{\mathrm{Y}}{1-\mathrm{Y}}=$ Opini audit going concern (variabel dummy di mana kode 1 untuk perusahaan yang menerima opini audit going concern dan kode 0 untuk perusahaan yang menerima opini audit non going concern)

$X_{1}=$ Rasio profitabilitas

$\mathrm{X}_{2}=$ Rasio likuiditas

$\mathrm{X}_{3}=$ Rasio solvabilitas

$\mathrm{B}_{0} \quad=$ Konstanta

$\beta_{1,2,3}=$ Koefisien regresi

$\varepsilon \quad=$ error (kesalahan residual)

Langkah-langkah dalam pengujian hipotesis menggunakan analisis regresi logistik biner (Binary Logistic Regression) yaitu, sebagai berikut:

1. Menilai keseluruhan model fit (Overall Model Fit Test)

2. Menilai kelayakan model regresi (Goodness of Fit Test)

3. Uji koefisien determinasi (Nagelkerke's $R$ Square)

4. Uji signifikansi parameter individual (Uji Hipotesis Parsial)

\section{Menilai Keseluruhan Model Fit (Overall Model Fit Test)}

Beberapa tes statistik diberikan untuk menilai overall fit model terhadap data, hipotesis untuk menilai model fit dengan data adalah sebagai berikut:

\section{HO: Model yang dihipotesakan fit dengan data} HA: Model yang dihipotesakan tidak fit dengan data

Hipotesis tersebut bermakna tidak menolak hipotesa nol agar model fit dengan data. Statistik yang digunakan berdasarkan pada fungsi likelihood. Likelihood $\mathrm{L}$ dari model adalah probabilitas bahwa model yang dihipotesakan mengggambarkan data input. Pada pengujian hipotesis nol dan alternatif, L ditransformasikan menjadi -2LogL. Statistik -2LogL kadangkadang disebut likelihood rasio $\mathrm{x}^{2}$ statistik, di mana $\mathrm{x}^{2}$ distribusi dengan degree of freedom $n-q$, dengan $q$ adalah jumlah parameter dalam model. Jika hasil -2LogL sebelum dimasukkan variabel independen kurang dari nilai signifikansi alpha 5\%, menunjukkan bahwa hipotesis nol tidak diterima yang berarti model dengan nilai konstanta saja tidak fit dengan data, sedangkan jika nilai -2LogL setelah dimasukkan variabel independen lebih dari nilai signifikansi alpha 5\%, menunjukkan bahwa hipotesis nol diterima dan model dengan nilai konstanta serta nilai variabel independen fit dengan data. (Ghozali, 2018).

\section{Menilai Kelayakan Model Regresi (Goodness of Fit Test)}


Hosmer and Lemeshow's Goodness of Fit Test menguji hipotesis nol bahwa data empiris cocok atau sesuai dengan model (tidak ada perbedaan antara model dengan data sehingga model dapat dikatakan fit). Jika nilai Hosmer and Lemeshow Goodness of Fit Test statistik sama dengan atau kurang dari 0.05, maka hipotesis nol ditolak yang berarti ada perbedaan signifikan antara model dengan nilai observasinya, sehingga Goodness of Fit model tidak baik karena model tidak dapat memprediksi nilai observasinya. Jika nilai statistik Hosmer and Lemeshow Goodness of Fit lebih besar dari 0.05, maka hipotesis nol tidak dapat ditolak dan berarti model mampu memprediksi nilai observasinya atau dapat dikatakan model diterima karena cocok dengan data observasinya (Ghozali, 2018)

\section{Uji Koefisien Determinasi $\left(\mathbf{R}^{2}\right)$}

Koefisien determinasi pada intinya mengukur seberapa jauh kemampuan model dalam menerangkan variasi variabel dependen. Nilai koefisien determinasi adalah antara nol dan satu. Nilai $\mathrm{R}^{2}$ yang kecil berarti kemampuan variabel-variabel independen dalam menjelaskan variabel dependen amat terbatas. Nilai yang mendekati satu berarti, variabelvariabel independen memberikan hampir semua informasi yang dibutuhkan untuk memprediksi variasi variabel dependen (Ghozali, 2018).

\section{Uji Signifikansi Parameter Individual (Uji Hipotesis Parsial)}

Uji hipotesis parsial digunakan untuk mengetahui pengaruh masingmasing variabel independen terhadap variabel dependen. Pada dasarnya, uji ini menunjukkan seberapa jauh pengaruh satu variabel penjelas/independen secara individual dalam menerangkan variasi variabel dependen. Pengujian dilakukan dengan tingkat signifikansi atau kepercayaan sebesar $0.05(a=5 \%)$. Kriteria pengambilan keputusan penerimaan atau penolakan dalam uji hipotesis dua arah yaitu, jika probabilitas lebih besar dari 0.025 maka variabel independen berpengaruh tidak signifikan terhadap variabel dependen atau dengan kata lain hipotesis penelitian tidak diterima sedangkan, jika probabilitas lebih kecil dari 0.025 maka variabel independen berpengaruh signifikan terhadap variabel dependen atau hipotesis dalam penelitian diterima (Ghozali, 2018).

\section{HASIL PENELITIAN DAN PEMBAHASAN}

\section{Analisis Statistik Deskriptif}

Uji statistik deskriptif menghasilkan rincian data sebagai berikut.

1) Profitabilitas

Profitabilitas sebagai variabel independen $\left(\mathrm{X}_{1}\right)$ dalam penelitian ini, diukur menggunakan rasio ROE (return on equity) atau hasil pengembalian ekuitas dengan nilai mean (rata-rata) sebesar -0.5067 , nilai minimum (terendah) yaitu -326.92 dan nilai maksimum (tertinggi) 
2.33. Secara teori, nilai rasio ROE yang semakin tinggi menunjukkan semakin baik kemampuan perusahaan dalam menghasilkan laba (keuntungan) serta efisiensi penggunaan modal.

Kemudian untuk range (rentang data) dari data terkecil dan terbesar dalam penelitian sebesar 329.25 dan sum (jumlah total data) adalah 316.67. Nilai sum yang negatif berarti bahwa lebih banyak nilai profitabilitas pada perusahaan sampel yang rendah, yang mengindikasikan banyak perusahaan sampel mengalami kerugian atau memiliki kemampuan yang rendah dalam menghasilkan laba.

Standar deviasi menunjukkan nilai sebesar 13.09289 dengan varian 171.424. Adapun nilai swekness menunjukkan angka sebesar -24.913 dengan estimasi error 0.98 , hal tersebut berarti bahwa bentuk distribusinya tidak simetris, melainkan menceng menuju ke satu sisi, yaitu tertarik ke kiri sehingga berbentuk negative skewed. Sedangkan, kurtosis senilai 622.046 dengan estimasi error 0.195 yang menunjukkan nilai data distribusinya meninggi di tengah dan bernilai positif sehingga disebut distribusi berbentuk leptokurtic.

Tabel 4.1: Deskriptif Statistik Profitabilitas Descriptive Statistic

\begin{tabular}{|c|c|c|c|c|c|c|}
\hline \multirow{4}{*}{$\begin{array}{c}\text { Profitabilita } \\
\text { s }\end{array}$} & $\begin{array}{l}\text { Range } \\
329.25 \\
\end{array}$ & $\begin{array}{c}\text { Min } \\
-326.92\end{array}$ & $\begin{array}{l}\text { Max } \\
2.33\end{array}$ & $\begin{array}{c}\text { Sum } \\
-3.16 .6 \\
\end{array}$ & $\begin{array}{r}1 \\
-0 \\
\end{array}$ & ean \\
\hline & & \multirow[b]{2}{*}{ Varian } & \multicolumn{2}{|c|}{ Sweknes } & \multicolumn{2}{|c|}{ Kurtosis } \\
\hline & $\begin{array}{c}\text { Sta.Devias } \\
\text { i }\end{array}$ & & Statistic & $\begin{array}{l}\text { Err } \\
\text { or }\end{array}$ & $\begin{array}{l}\text { Statisti } \\
\text { C }\end{array}$ & Error \\
\hline & 13.09289 & $\begin{array}{c}171.42 \\
4\end{array}$ & -24.913 & $\begin{array}{l}0.0 \\
98\end{array}$ & $\begin{array}{c}622.04 \\
6\end{array}$ & $\begin{array}{c}0.19 \\
5\end{array}$ \\
\hline
\end{tabular}

Sumber: Data diolah, 2021.

2) Likuiditas

Likuiditas adalah variabel yang mencerminkan kemampuan perusahaan dalam memenuhi kewajiban jangka pendeknya dan merupakan variabel $X_{2}$ dalam penelitian ini, yang diukur dengan menggunakan cash ratio. Hasil analisis statistik deskriptif menunjukkan karakteristik dari data likuiditas, yaitu mean/nilai rata-rata sampel senilai 0.6119 , nilai maksimum 43.40 dan nilai minimum 0.00 .

Nilai tertinggi mencapai 43.40 yang artinya perusahaan memiliki nilai kas 43 kali dari jumlah nilai utang lancarnya. Sementara itu, untuk perusahaan yang memiliki nilai rasio likuiditas 0 berarti bahwa perusahaan tersebut tidak memiliki kemampuan untuk melunasi kewajiban jangka pendeknya serta tidak dapat mempertahankan kelangsungan hidupnya dan terancam dilikuidasi. 
Adapun range atau selisih dari nilai maksimum dan minimum adalah 43.40 karena nilai minimum adalah angka 0.00 sedangkan untuk nilai sum/jumlah keseluruhan data mencapai 382.46. Standar deviasi atau rata-rata penyimpangan variabel dari nilai yang diharapkan yaitu nilai rata-ratanya, sebesar 2.10604 dan varian atau nilai dari deviasi standar kuadrat sebesar 4.435. Selanjutnya untuk pengukur bentuk, swekness dan kurtosis keduanya menunjukkan nilai yang positif. Nilai swekness menunjukkan angka 14.661 dengan nilai error 0.98 yang berarti bahwa data menyimpang dari bentuk simteris dengan condong ke kanan sehingga disebut positively skewed. Sedangkan, untuk kurtosis menunjukkan angka 278.713 dengan nilai error 0.195 yang berarti bahwa data juga tidak terdistribusi merata melainkan, distribusi berbentuk meninggi di tengah yang disebut bentuk leptokurtic.

Tabel 4.2: Deskriptif Statistik Likuiditas

\begin{tabular}{ccccccc}
\hline \multicolumn{7}{c}{ Descriptive Statistic } \\
\hline \multirow{4}{*}{ Likuiditas } & Range & Min & Max & Sum & Mean \\
\cline { 2 - 7 } & 43.40 & 0.00 & 43.40 & 382.46 & 0.6119 \\
\cline { 2 - 7 } & \multirow{2}{*}{ Std.Deviasi } & \multirow{2}{*}{ Varian } & \multicolumn{2}{c}{ Sweknes } & Kurtosis \\
\cline { 2 - 7 } \cline { 3 - 7 } & & Statistic & Error & Statistic & Error \\
\cline { 2 - 7 } & 2.10604 & 4.435 & 14.661 & 0.098 & 278.713 & 0.195 \\
\hline
\end{tabular}

Sumber: Data diolah, 2021.

3) Solvabilitas

Solvabilitas sebagai variabel $X_{3}$ dalam penelitian ini mencerminkan kemampuan perusahaan dalam memenuhi seluruh kewajibannya, yaitu kewajiban jangka pendek dan kewajiban jangka panjang, dengan rasio DER (debt to equity ratio) sebagai indikator ukurnya. Hasil uji terhadap data solvabilitas dengan analisis statistik deskriptif yang telah diolah menunjukkan angka bahwa, mean sebesar 2.0566, nilai maksimum 370.57, nilai minimum -7.94, range (selisih) senilai 378.51 dan sum untuk total keseluruhan data senilai 1285.40 .

Adapun nilai standar deviasi sebesar 15.28531 dan varian menunjukkan angka statistik 233.641. Kemudian nilai swekness menunjukkan angka sebesar 22.780 dengan nilai error untuk swekness 0.98 sedangkan untuk kurtosis sebesar 544.907 dengan nilai error 0.195 . Kedua pengukur bentuk distribusi data tersebut menunjukkan distribusi data yang tidak berbentuk simetris dan tidak merata sehingga disebut berbentuk positively skewed yang menggambarkan swekness menceng ke kanan dan leptokurtic yang menggambarkan distribusi data meninggi di tengah.

\section{Tabel 4.3: Deskriptif Statistik Solvabilitas}




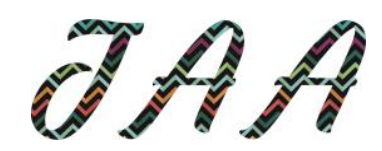

Vol. 6, No. 1, Oktober 2021

\begin{tabular}{|c|c|c|c|c|c|c|}
\hline \multicolumn{7}{|c|}{ Descriptive Statistic } \\
\hline \multirow{5}{*}{$\begin{array}{c}\text { Solvabilita } \\
\text { s }\end{array}$} & Range & Min & Max & Sum & & ean \\
\hline & 378.51 & -7.94 & 370.57 & 1285.40 & & 0566 \\
\hline & \multirow[b]{2}{*}{$\begin{array}{c}\text { Std.Devias } \\
\text { i }\end{array}$} & \multirow[b]{2}{*}{ Varian } & \multicolumn{2}{|c|}{ Sweknes } & \multicolumn{2}{|c|}{ Kurtosis } \\
\hline & & & Statistic & $\begin{array}{l}\text { Err } \\
\text { or }\end{array}$ & Statistic & Error \\
\hline & 15.28531 & $\begin{array}{c}233.64 \\
1\end{array}$ & 22.780 & $\begin{array}{l}0.0 \\
98\end{array}$ & $\begin{array}{c}544.90 \\
7\end{array}$ & 0.195 \\
\hline
\end{tabular}

Sumber: Data diolah, 2021.

4) Opini Audit

Variabel opini audit dalam penelitian ini diukur menggunakan variabel dummy, dengan pemberian kode 0 untuk perusahaan yang menerima opini audit non going concern dan kode 1 untuk perusahaan yang menerima opini audit going concern. Berdasarkan hasil uji statistik dapat dianalisis bahwa nilai mean (rata-rata) dari keseluruhan data yaitu 0.03 , dengan nilai minimum (terkecil) sebesar 0 dan nilai maksimum (terbesar) yaitu 1 sesuai dengan kode klasifikasi nilai dengan variabel dummy, sedangkan range (selisih nilai terbesar dan terkecil) adalah 1 dan nilai sum yaitu jumlah keseluruhan data jika diakumulasikan senilai 18 yang sesuai dengan jumlah frekuensi perusahaan yang menerima opini audit going concern.

Secara keseluruhan dapat dianalisis dari data-data sampel penelitian, perusahaan sampel yang menerima opini audit going concern dikarenakan perusahaan mengalami kerugian sangat besar dan berturut-berturut yang dinilai auditor tidak dapat efektif untuk diselesaikan melalui rencana manajemen yang dilampirkan dalam catatan atas laporan keuangan bahkan tidak ada penjelasan rencana yang efektif dan efisien untuk mengatasi kondisi tersebut, serta pengungkapan yang dinilai belum memadai atas kondisi keraguan keberlangsungan usaha tersebut, yang menjadi dasar pertimbangan auditor dalam memberikan opini audit going concern.

Selanjutnya deviasi standar yang merupakan rata-rata penyimpangan masing-masing variabel terhadap nilai yang diharapkan yaitu nilai rata-ratanya, untuk variabel opini audit senilai 0.167 dan varian sebesar 0.28 yaitu, nilai dari deviasi standar kuadrat. Pengukur bentuk berupa swekness yang mengukur penyimpangan distribusi data dari bentuk simetrisnya menunjukkan angka sebesar 5.648 dengan estimasi error yaitu 0.98 . Nilai swekness yang bernilai positif berarti bahwa bentuk distribusinya adalah positive skewed. Sedangkan, nilai kurtosis yaitu pengukur ketinggian atau kerataan dari distribusi data menunjukkan angka senilai 30.001 dengan estimasi error 0.195, karena 
nilai kurtosis juga bernilai positif dapat disimpulkan bahwa bentuk distribusi yang digambarkan oleh data penelitian adalah leptokurtic.

Tabel 4.4: Deskriptif Statistik Opini Audit Descriptive Statistic

\begin{tabular}{|c|c|c|c|c|c|c|}
\hline \multirow{5}{*}{$\begin{array}{l}\text { Opini } \\
\text { Audit }\end{array}$} & Range & Min & Max & Sum & & Mean \\
\hline & 1 & 0 & 1 & 18 & & 0.03 \\
\hline & \multirow{2}{*}{ Std.Deviasi } & \multirow{2}{*}{ Varian } & \multicolumn{2}{|c|}{ Sweknes } & \multicolumn{2}{|c|}{ Kurtosis } \\
\hline & & & Statistic & Error & Statistic & Error \\
\hline & 0.167 & 0.028 & 5.648 & 0.098 & 30.001 & 0.195 \\
\hline
\end{tabular}

Sumber: Data diolah, 2021.

\section{Analisis Uji Asumsi Klasik}

Penelitian ini menggunakan uji regresi logistik untuk menganalisis pengaruh yang terjadi antara variabel-variabel independen terhadap variabel dependen, hal itu dikarenakan variabel $Y$ (dependen) berbentuk variabel dummy yang berskala kategori dengan dua kateogi yaitu, perusahaan yang menerima opini audit going concern dan perusahaan yang menerima opini audit non going concern.

Gregory dan Bader (2018) dalam artikel yang berjudul Logistic and Linear Regression Assumptions. Violation Recognition and Control menyatakan:

"Uji regresi logistik sangat berbeda dengan uji regresi linear pada umumnya, karena uji regresi logistik tidak mengharuskan beberapa asumsi utama yang diharuskan oleh model linear dan model linear umum (serta model berbasis algoritma kuadrat terkecil biasa lainnya) seperti, regresi logistik tidak memerlukan hubungan linear antara variabel independen dan variabel dependen, error term (residual) tidak perlu berdistribusi normal, homoskedastisitas tidak diperlukan, dan variabel dependen dalam regresi logistik tidak diukur pada suatu interval atau skala rasio".

Oleh karena itu, uji asumsi klasik yang dilakukan dalam penelitian ini hanya meliputi uji multikolonieritas.

1) Uji Multikolonieritas

Hasil uji multikolonieritas pada tiga variabel independen dalam penelitian ini yaitu profitabilitas, likuiditas, dan solvabilitas menunjukkan tidak terjadi masalah multikolonieritas pada data sampel yang diuji. Hal tersebut terbukti dengan nilai tolerance pada setiap variabel independen lebih dari 0.10 dan nilai VIF kurang dari 10 , seperti yang ditunjukkan pada tabel berikut. 
Tabel 4.5: Uji Multikolonieritas

Coeffisient $^{\mathrm{a}}$

\begin{tabular}{cccc}
\hline \multicolumn{4}{c}{ Collinearity Statistic } \\
\hline Model & & Tolerance & VIF \\
\hline 1 & Profitabilitas & 0.998 & 1.002 \\
\hline & Likuiditas & 0.750 & 1.334 \\
\hline & Solvabilitas & 0.751 & 1.331 \\
\hline
\end{tabular}

Keterangan: a. Dependent Variable Opini Audite

Sumber: Data diolah, 2021.

\section{Analisis Regresi Logistik}

Analisis regresi logistik digunakan dalam penelitian ini karena variabel dependen yang bersifat kategori atau berbentuk dikotomus, yang terdiri dari dua kategori yaitu opini audit going concern dan opini audit non going concern. Jika berdasarkan variabel $Y$, penelitian termasuk dalam kelompok penelitian yang dapat diuji dengan analisis regresi logistik sedangkan jika ditinjau lebih lagi dari variabel $X$ yang mencakup tiga variabel penelitian maka dapat disimpulkan penelitian ini disebut sebagai analisis regresi logistik berganda. Adapun uji yang dilakukan dalam analisis regresi logistik berganda (binary logistic) mencakup tahapan prosedur sebagai berikut:

\section{1) Menilai Keseluruhan Model Fit (Overall Model Fit Test)}

Hasil uji terhadap keseluruhan model fit ditunjukkan pada tabel iteration history yang menggambarkan nilai statistik -2LogL Block 0 : Beginning Block yang artinya, tanpa ada variabel independen yang dimasukkan ke dalam model. Dalam model tersebut variabel $Y$ hanya diasumsikan diprediksi melalui nilai konstanta sebesar 76.534 dengan degree of freedom $(\mathrm{DF})=\mathrm{n}-1$ yaitu, $613-1=612$. Nilai chi-square $\left(\mathrm{X}^{2}\right)$ tabel pada df 612 dengan probabilitas 0.05 adalah 670.661, yang mana nilai tersebut lebih besar dari nilai -2 Log Likelihood 76.534 sehingga menunjukkan bahwa HO diterima yang berarti, model yang dihipotesakan fit dengan data walaupun hanya menggunakan nilai konstanta saja. Dapat disimpulkan pula bahwa nilai -2 Log Likelihood 76.534 tidak signifikan pada alpha $5 \%$ yang berarti hipotesis nol tidak dapat ditolak dan model fit dengan data.

Selanjutnya setelah dimasukkan tiga variabel independen yaitu variabel profitabilitas, likuiditas, dan solvabilitas mengakibatkan nilai 2LogL Block 1: Method = Enter turun menjadi 12.378, yang mana nilai tersebut juga lebih kecil dari nilai chi square $\left(X^{2}\right)$ dengan df $613-3$ $1=609$ yaitu, 667.519 yang artinya hipotesis nol tidak dapat ditolak dan model fit dengan data.Terjadinya penurunan pada nilai -2 Log Likelihood sebesar 64.156 (76.534 - 12.378) menunjukkan bahwa semakin baiknya model yang dihipotesakan untuk memprediksi pemberian opini audit going concern setelah tiga variabel independen yaitu profitabilitas, 
likuiditas, dan solvabilitas dimasukkan ke dalam model dengan tingkat signifikansi alpha $5 \%$.

Tabel 4.6: Uji Overall Model Fit Test

\begin{tabular}{|c|c|c|c|c|c|}
\hline \multicolumn{6}{|c|}{ Iteration History } \\
\hline \multicolumn{3}{|c|}{$\begin{array}{c}\text { Block 0: } \\
\text { Beginning Block }\end{array}$} & \multicolumn{3}{|c|}{$\begin{array}{c}\text { Block 1: } \\
\text { Method = Enter }\end{array}$} \\
\hline \multicolumn{2}{|c|}{ Iteration } & \multirow{2}{*}{$\begin{array}{c}-2 \text { Log } \\
\text { Likelihood } \\
189.785\end{array}$} & \multicolumn{2}{|c|}{ Iteration } & \multirow{2}{*}{$\begin{array}{c}-2 \text { Log Likelihood } \\
189.431\end{array}$} \\
\hline Step 0 & 1 & & Step 1 & 1 & \\
\hline & 2 & 101.971 & & 2 & 100.756 \\
\hline & 3 & 80.448 & & 3 & 76.957 \\
\hline & 4 & 76.763 & & 4 & 68.308 \\
\hline & 5 & 76.536 & & 5 & 60.036 \\
\hline & 6 & 76.534 & & 6 & 41.448 \\
\hline & 7 & 76.534 & & 7 & 26.536 \\
\hline & & & & 8 & 19.501 \\
\hline & & & & 9 & 15.925 \\
\hline & & & & 10 & 13.839 \\
\hline & & & & 11 & 12.678 \\
\hline & & & & 12 & 12.393 \\
\hline & & & & 13 & 12.378 \\
\hline & & & & 14 & 12.378 \\
\hline & & & & 15 & 12.378 \\
\hline
\end{tabular}

Sumber: Data diolah, 2021.

\section{2)Menilai Kelayakan Model Regresi (Goodness of Fit Test)}

Hosmer and Lemeshow's Goodness of Fit Test adalah tes yang menguji hipotesis nol bahwa data empiris cocok/sesuai dengan model yang artinya, tidak ada perbedaan antara model dengan data. Dasar pengambilan keputusan dalam uji kelayakan model regresi ini adalah, jika nilai statistik Hosmer and Lemeshow Goodness of Fit Test sama dengan atau kurang dari 0.05 , maka hipotesis nol ditolak yang berarti ada perbedaan signifikan antara model dengan nilai observasinya sehingga goodness of fit model dikatakan tidak baik, karena model tidak dapat memprediksi nilai observasi. Sebaliknya, jika nilai statistik hosmer and lemeshow goodness of fit lebih besar dari 0.05 maka hipotesis nol diterima atau tidak dapat ditolak yang berarti, model mampu memprediksi nilai observasinya atau dapat dikatakan model dapat diterima karena cocok dengan data observasinya.

Berdasarkan hasil uji statistik pada SPSS dapat disimpulkan bahwa hipotesis nol diterima. Hal tersebut dibuktikan dengan nilai signifikansi yaitu 1.000, yang mana nilai tersebut lebih besar dari 0.05 sehingga 


\section{DA}

Vol. 6, No. 1, Oktober 2021

model dapat dikatakan fit karena tidak ada perbedaan yang signifikan antara data yang diuji dengan model regresi yang dibentuk dan model regresi dapat dengan baik digunakan untuk memprediksi nilai variabel yang diuji.

Tabel 4.7: Uji Goodness of Fit Test Hosmer and Lemeshow Test

\begin{tabular}{cccc}
\hline Step & Chi-square & df & Sig. \\
\hline 1 & 0.000 & 8 & 1.000 \\
\hline
\end{tabular}

Sumber: Data diolah, 2021.

Selanjutnya tabel klasifikasi $2 \times 2$ menghitung nilai estimasi yang benar dan yang salah, artinya pada kolom terdapat dua nilai prediksi dari dua variabel dependen yaitu opini audit going concern dan opini audit non going concern, sedangkan pada tabel baris menunjukkan nilai observasi sesungguhnya dari variabel dependen opini audit going concern dan opini audit non going concern.

Berdasarkan hasil dalam tabel klasifikasi, menunjukkan hasil prediksi perusahaan yang mendapatkan opini audit non going concern adalah 606 perusahaan sedangkan hasil observasi hanya 604 perusahaan, jadi ketepatan klasifikasi $99.7 \%$ (604/606). Adapun perusahaan yang mendapatkan opini audit going concern ada 7 perusahaan, sedangkan hasil observasi hanya terdapat 6 perusahaan yang mendapatkan opini audit going concern, sehingga dapat disimpulkan ketepatan klasifikasi adalah $85.7 \%(6 / 7)$ atau secara keseluruhan dapat disimpulkan ketepatan klasifikasi adalah 99.5\%.

Tabel 4.8: Klasifikasi Opini Audit.

Classification Table

\begin{tabular}{|c|c|c|c|c|c|}
\hline \multicolumn{3}{|c|}{ Observed } & & & \\
\hline \multirow[t]{4}{*}{ Step 1} & \multirow{3}{*}{\multicolumn{2}{|c|}{$\begin{array}{l}\text { Opini } \\
\text { Audit }\end{array}$}} & \multicolumn{3}{|c|}{ Predicted } \\
\hline & & & \multicolumn{2}{|c|}{ Opini Audit } & \multirow[b]{2}{*}{$\begin{array}{c}\text { Percentage } \\
\text { Correct }\end{array}$} \\
\hline & & & $\begin{array}{l}\text { Opini Audit Non } \\
\text { Going Concern }\end{array}$ & $\begin{array}{l}\text { Opini Audit } \\
\text { Going } \\
\text { Concern }\end{array}$ & \\
\hline & & $\begin{array}{l}\text { Opini } \\
\text { Audit } \\
\text { Non } \\
\text { Gong } \\
\text { Concer } \\
n\end{array}$ & 604 & 2 & 99.7 \\
\hline
\end{tabular}


Classification Table

\begin{tabular}{|c|c|c|c|c|c|}
\hline \multicolumn{3}{|c|}{ Observed } & & & \\
\hline \multirow[t]{3}{*}{ Step 1} & Opini & & \multicolumn{3}{|c|}{ Predicted } \\
\hline & & & \multicolumn{2}{|c|}{ Opini Audit } & \multirow[b]{2}{*}{$\begin{array}{c}\text { Percentage } \\
\text { Correct }\end{array}$} \\
\hline & & & $\begin{array}{l}\text { Opini Audit Non } \\
\text { Going Concern }\end{array}$ & $\begin{array}{l}\text { Opini Audit } \\
\text { Going } \\
\text { Concern }\end{array}$ & \\
\hline & & $\begin{array}{l}\text { Opini } \\
\text { Audit } \\
\text { Going } \\
\text { Concer } \\
\text { n }\end{array}$ & 1 & 6 & 85.7 \\
\hline Overal & Percent & & & & 99.5 \\
\hline
\end{tabular}

Sumber: Data diolah, 2021.

\section{3)Uji Koefisien Determinasi (Nagelkerke's R Square)}

Dengan meninjau hasil uji koefisien determinasi, dapat diukur kemampuan model regresi dalam menerangkan variasi variabel dependen. Nilai cox and snell $R$ square merupakan ukuran yang mencoba meniru ukuran $\mathrm{R}^{2}$ pada multiple regression, yang didasarkan pada teknik estimasi likelihood dengan nilai maksimum kurang dari satu sehingga sulit untuk diinterpretasikan. Sedangkan nilai nagelkerke's $R$ square merupakan modifikasi dari koefisien cox dan snell untuk memastikan bahwa nilainya bervariasi dari nol sampai satu dengan cara membagi nilai cox dan snell $R^{2}$ dengan nilai maksimumnya.

Hasil uji statistik pada SPSS menunjukkan nilai Nagelkerke $R$ Square sebesar 0.847 yang artinya, kemampuan model prediksi untuk memberikan penjelasan terhadap faktor-faktor yang mempengaruhi pemberian opini audit going concern ditinjau dari beberapa faktor seperti profitabilitas, likuiditas, dan solvabiliitas adalah sebesar $84.7 \%$ sedangkan $15.3 \%$ dapat dijelaskan oleh faktor-faktor lain di luar penelitian.

Tabel 4.9: Uji Nagelkerke's R Square Model Summary

\begin{tabular}{cccc}
\hline Step & $\begin{array}{c}-\mathbf{2} \text { Log } \\
\text { Likelihood }\end{array}$ & $\begin{array}{c}\text { Cox and Snell R } \\
\text { Square }\end{array}$ & $\begin{array}{c}\text { Nagelkerke } \\
\mathbf{R} \\
\text { Square }\end{array}$ \\
\hline 1 & 12.378 & 0.099 & 0.847 \\
\hline
\end{tabular}

Sumber: Data diolah, 2021.

\section{4)Uji Signifikansi Parameter Individual (Uji Statistik Parsial)}

Berdasarkan hasil uji signifikansi paremater individual dapat dijawab hipotesis dalam penelitian ini, yaitu tentang bagaimana pengaruh secara 
parsial dari masing-masing variabel independen terhadap variabel dependen dengan bentuk model persamaan regresi logistik sebagai berikut:

$$
\operatorname{Ln} \frac{\mathrm{Y}}{1-\mathrm{Y}}=-6.647+\left(0.130 X_{1}\right)-\left(15.446 X_{2}\right)-\left(12.448 X_{3}\right)+\varepsilon
$$

Nilai konstanta dalam persamaan model regresi tersebut menunjukkan angka sebesar -6.647 yang artinya, jika semua variabel independen dianggap konstan maka probabilitas penerimaan opini audit going concern berkurang senilai 6.647. Adapun nilai koefisien untuk variabel profitabilitas sebesar 0.130 yang berarti, setiap kenaikan $1 \%$ pada nilai profitabilitas sebuah perusahaan akan meningkatkan probabilitas pemberian opini audit going concern oleh auditor ekstenal (akuntan publik) sebesar 0.130 dengan asumsi untuk variabel lainnya dianggap konstan.

Variabel likuiditas memiliki nilai koefisien sebesar -15.446 yang artinya, setiap penurunan $1 \%$ pada tingkat likuiditas perusahaan akan mengakibatkan peningkatan probabilitas perusahaan untuk menerima opini audit going concern sebesar 15.446 dengan asumsi variabel lain dianggap konstan, dan terakhir koefisien dari variabel solvabilitas yang menunjukkan nilai koefisien -12.448 dengan asumsi yang sama yaitu variabel lain dianggap konstan, maka hal tersebut menunjukkan bahwa setiap penurunan $1 \%$ pada nilai solvabilitas maka akan berdampak pada peningkatan probabilitas penerimaan opini audit going concern pada suatu perusahaan sebesar 12.448 .

Ditinjau berdasarkan nilai signifikansi per variabel dapat dianalisis dan dijawab hipotesis dalam penelitian, yaitu dari nilai variabel profitabilitas dengan nilai signifikansi 0.807 yang menunjukkan angka lebih besar dari 0.025. Dari perbandingan tersebut dapat ditarik kesimpulan bahwa hipotesis $\left(\mathrm{H}_{1}\right)$ dalam penelitian ini tidak diterima. Hasil penelitian membuktikan profitabilitas berpengaruh tidak signifikan terhadap penerimaan opini audit going concern pada suatu perusahaan, begitu pun dengan variabel likuiditas yang juga menunjukkan hasil yang sama, di mana dengan nilai signifikansi sebesar 0.214 yang lebih besar dari 0.025 yang berarti hipotesis $\left(\mathrm{H}_{2}\right)$ dalam penelitian juga tidak diterima. Hasil penelitian membuktikan likuiditas berpengaruh tidak signifikan terhadap opini audit going concern.

Akan tetapi, untuk variabel solvabilitas menunjukkan angka nilai signifikansi sebesar 0.011 yang berarti lebih kecil dari 0.025 , sehingga dapat disimpulkan untuk variabel ini hipotesis $\left(\mathrm{H}_{3}\right)$ dalam penelitian diterima. Hal tersebut berarti variabel solvabilitas berpengaruh signifikan terhadap penerimaan opini audit going concern. 


\begin{tabular}{ccccc}
\hline \multicolumn{5}{c}{ Tabel 4.10: Uji Parsial } \\
Variables in the Equation \\
\hline & B & df & Sig. \\
\hline Step 1 & Profitabilitas & 0.130 & 1 & 0.807 \\
\hline Likuiditas & -15.446 & 1 & 0.214 \\
\hline Solvabilitas & -12.448 & 1 & 0.011 \\
\hline Constant & -6.647 & 1 & 0.027 \\
\hline
\end{tabular}

Sumber: Data diolah, 2021.

\section{Pembahasan}

Pengaruh profitabilitas, likuiditas, dan solvabilitas terhadap opini audit going concern pada perusahaan sektor jasa yang terdaftar di Bursa Efek Indonesia tahun 2015-2019 diketahui berdasarkan hasil pengujian secara parsial, variabel profitabilitas $\left(X_{1}\right)$ dan likuiditas $\left(X_{2}\right)$ menunjukkan masing-masing pengaruh yang tidak signifikan untuk peluang atau probabilitas penerimaan opini audit going concern, sedangkan untuk variabel solvabilitas $\left(X_{3}\right)$ justru menunjukkan hasil pengujian secara parsial yang berpengaruh signifikan terhadap penerimaan opini audit going concern. Berikut adalah pembahasan analisis terhadap hasil uji dari masingmasing variabel tersebut.

\section{Pengaruh Profitabilitas Terhadap Opini Audit Going Concern}

Profitabilitas berdasarkan hasil analisis uji regresi logistik dengan uji secara parsial menunjukkan angka statistik siginifikansi 0.807, yang mana nilai tersebut lebih besar dari 0.025 sehingga dapat disimpulkan bahwa Hipotesis $1\left(\mathrm{H}_{1}\right)$ dalam penelitian tidak diterima, yang artinya bahwa profitabilitas berpengaruh tidak signifikan terhadap opini audit going concern. Rasio profitabilitas yang ditunjukkan dengan nilai ROE yang tinggi pada umumnya menunjukkan bahwa kondisi perusahaan yang semakin baik dengan posisi pemilik perusahaan yang semakin kuat, melalui peningkatan deviden yang diperoleh dari laba bersih.

Meskipun demikian, dibalik hal tersebut tidak dapat dipungkiri bahwa perusahaan dengan profitabilitas yang tinggi belum tentu terjamin keberlangsungan usahanya, seperti dalam kasus kebangkrutan Lehman Brothers yang merupakan perusahaan bidang investasi dan jasa di Amerika Serikat dengan kondisi perusahaan yang sudah mapan dengan profitabilitas tinggi, namun secara tiba-tiba dinyatakan pailit pada 15 September 2008 (Purba, 2016). Peristiwa tersebut adalah salah satu kasus kepailitan terbesar di Amerika Serikat yang berimbas kepada ekonomi global.

Adapun terhadap data sampel yang diuji dalam penelitian dengan nilai ROE yang tertinggi justru tidak menunjukkan tingkat profitabilitas yang baik, sebaliknya perusahaan sampel mengalami jumlah kerugian yang besar kemudian berbanding dengan defisiensi ekuitas sehingga memiliki nilai ROE 


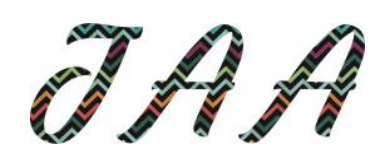

Vol. 6, No. 1, Oktober 2021

yang tinggi. Kondisi tersebut dapat diinterpretasikan menunjukkan kondisi pemilik perusahaan tidak mendapatkan deviden atas modal yang telah disetorkannya, melainkan harus menanggung kerugian akibat kegagalan perusahaan dalam memperoleh laba.

Oleh karena itu, dalam menentukan opini audit untuk suatu perusahaan, KAP harus menelaah secara teliti setiap kondisi komponen rasio keuangan yang terkandung dalam laporan keuangan serta kevalidan atas informasi tersebut sesuai dengan kode etik profesi akuntan publik dalam pernyataan Nomor 1 Tentang Integritas, Objektivitas, dan Independensi serta pernyataan etika profesi Nomor 2 Tentang Kecakapan Profesional (Agoes, 2011). Auditor harus dapat secara objektif dalam menilai kondisi perusahaan, salah satunya terkait profitabilitas perusahaan. Nilai profitabilitas yang tinggi harus dianalisis dengan baik terkait dengan perolehan angka-angka yang membentuknya, apakah tidak terdapat salah saji yang material. Hal itu sesuai dengan peran auditor dalam teori agensi, yaitu sebagai pihak independen yang dipercaya oleh principa/ untuk menilai kinerja agent atau manajer perusahaan. Auditor harus bebas dari benturan kepentingan dengan kata lain bersikap netral (independen) dan tidak memihak atau condong kepada salah satu kepentingan pihak dalam kontrak agensi sebuah perusahaan.

Nilai koefisien yang dihasilkan untuk variabel profitabilitas dalam persamaan model regresi yaitu sebesar 0.130 , yang berarti bahwa terdapat pengaruh positif antara profitabilitas dengan opini audit going concern. Jika nilai profitabilitas naik sebesar $1 \%$ dengan asumsi faktor-faktor lainnya yang mempengaruhi pemberian opini audit going concern dianggap tetap, maka akan berdampak kepada peningkatan probabilitas penerimaan opini audit going concern.

Hal tersebut sesuai dengan konsep teori keagenan, bahwa auditor harus menjamin kewajaran atas laba yang dilaporkan dan mewaspadai setiap laba yang dilaporkan manajer, karena laba yang tinggi seringkali menjadi indikasi yang menunjukkan adanya perilaku oportunistik oleh pihak agent dalam kontrak kerja demi memperoleh kompensasi (bonus) yang tinggi. Pertumbuhan laba setiap tahunnya harus ditelaah kewajarannya, meskipun dalam hubungan berdasarkan tingkat signifikansi pada penelitian ini menunjukkan hubungan yang berpengaruh tidak signifikan, hal tersebut dalam rangka antisipasi kemungkinan adanya perilaku oportunistik agent.

Berdasarkan hasil uji terhadap perusahaan sampel dalam penelitian, dapat dianalisis bahwa kondisi profitabilitas yang tidak baik atau mengalami kerugian tidak semuanya mendapatkan opini audit dengan modifikasi mengenai going concern, seperti pada perusahaan PT Smartfren Telecom, PT Mitra International Resources, PT Express Transindo Utama, dan lainnya. Auditor independen menjelaskan dan mengungkapkan tentang kondisi defisit atau kerugian yang dialami oleh perusahaan sampel dalam pernyataan opini audit maupun catatan atas laporan keuangan, namun 
menyatakan tidak ada modifikasi atas opini audt yang diberikan dengan kata lain perusahaan tetap mendapatkan opini audit wajar tanpa pengecualian. Meskipun, ada keraguan yang dinyatakan auditor atas keberlangsungan usaha perusahaan tersebut. Hal itu berdasarkan pertimbangan auditor mengenai kecukupan bukti audit atas perusahaan auditee, tidak ada salah saji yang material, serta pengungkapan secara wajar yang telah dilakukan perusahaan. Terkait dengan keraguan atas kondisi keberlangsungan usaha sesuai dengan Tabel 2.1, penerimaan opini audit non going concern oleh sebagian besar perusahaan sampel yang meski mengalami kerugian mencapai tingkat keraguan signifikan antara $20 \%$ hingga $49 \%$, sehingga dalam laporan auditor independen yang dikeluarkan KAP diungkapkan mengenai hal tersebut, penyebabnya, dan juga rencana yang dilakukan manajemen untuk menyesuaikan kebijakan atau strategi dalam mengatasinya dan berdampak pada tidak dilakukannya modifikasi atas opini audit karena semua pengungkapan telah dilakukan secara memadai dan rencana manajemen dianggap efektif untuk mengatasi kerugian yang dialami sehingga dapat tetap going concern. Oleh karena itu, berdasarkan hasil uji regresi logisitik diketahui bahwa faktor profitabilitas berpengaruh tidak signifikan terhadap opini audit going concern.

Hasil penelitian ini menunjukkan hal yang selaras dengan penelitian sebelumnya yang meneliti terhadap faktor yang sama namun dengan sampel jenis perusahaan yang berbeda dan pada tahun penelitian yang berbeda pula. Penelitian terdahulu yang menyimpulkan juga bahwa profitabilitas berpengaruh tidak signifikan terhadap opini audit going concern seperti penelitian dari Aliah (2015), Atikoh (2017), Anita (2017), Nugroho et al., (2018), Wibisono (2019), Ambarwati dan Suwarno (2019), serta Purba dan Nazir (2019). Namun, bertolak belakang dengan hasil penelitian dari Rahman dan Ahmad (2018), Tryansyah dan Khairunnisa (2019), Bayudi dan Wirawati (2017), Kurbani et al., (2019), serta Haryanto dan Sudarno (2019) yang menyatakan bahwa profitabilitas berpengaruh signifikan terhadap opini audit going concern.

\section{Pengaruh Likuiditas Terhadap Opini Audit Going Concern}

Likuiditas merupakan kemampuan perusahaan dalam memenuhi kewajiban jangka pendeknya. Dalam penelitian ini nilai koefisien likuiditas menunjukkan nilai yang negatif sebesar -15.446 , yang artinya terdapat pengaruh yang negatif antara tingkat likuiditas perusahaan dengan probabilitas penerimaan opini audit going concern. Jika terjadi penurunan likuiditas perusahaan sebesar $1 \%$ maka akan mengakibatkan kenaikan peluang penerimaan opini audit going concern perusahaan sebesar 15.446. Namun hasil tingkat signifikansi untuk variabel tersebut bernilai 0.214 yang lebih besar dari 0.025 sehingga dapat disimpulkan bahwa hipotesis $2\left(\mathrm{H}_{2}\right)$ tidak diterima, yang artinya variabel likuiditas berpengaruh tidak signifikan terhadap penerimaan opini audit going concern. 


\section{DA}

Vol. 6, No. 1, Oktober 2021

Beberapa hasil penelitian terdahulu yang menunjukkan hasil yang sama bahwa likuiditas berpengaruh tidak signifikan terhadap opini audit going concern di antaranya seperti penelitian dari Yaqin dan Sari (2015), Bayudi dan Wirawati (2017), Pradika (2017), Wardani (2017), Atikoh (2017), Anita (2017), Nugroho et al (2018), Rahman dan Ahmad (2018), Wibisono (2019), Ambarwati dan Suwarno (2019), Purba dan Nazir (2019), serta Haryanto dan Sudarno (2019). Meskipun penelitian dari Kurbani et al., (2019) menunjukkan hasil bahwa likuiditas berpengaruh signifikan terhadap opini audit going concern.

Hasil penelitian ini membuktikan bahwa likuiditas berpengaruh tidak signifikan, hal tersebut terjadi karena dari sisi likuiditas perusahaan hanya mengukur kemampuan perusahaan untuk melunasi kewajibannya dalam jangka pendek, yaitu yang kurang dari 1 tahun sedangkan opini audit going concern diberikan dengan pertimbangan analisis kondisi keuangan perusahaan selama satu tahun laporan keuangan dengan kata lain dalam waktu yang relatif panjang.

Kondisi keuangan perusahaan yang sedang tidak baik atau dalam likuiditas buruk tidak cukup mencerminkan bahwa perusahaan tidak akan mampu untuk mempertahankan kelangsungan hidup usahanya. Berdasarkan teori stakeholder diungkapkan bahwa perubahan lingkungan yang tidak pasti menjadi masalah utama yang sering dihadapi para manajer dalam mengelola perusahaan dengan efisien dan efektif. Ketidakpastian perubahan lingkungan yang berdampak signifikan terhadap perkembangan usaha bukan sepenuhnya menjadi kesalahan para manajer, karena kondisi lingkungan yang tidak terkendali dan tidak dapat teratasi, seperti misalnya bencana alam maupun bencana non alam yang menyebabkan perusahaan mengalami kerugian besar sehingga tidak bisa terhindar dari masalah likuiditas.

Analisis terhadap perusahaan sampel penelitian juga menunjukkan banyak perusahaan yang mendapatkan opini audit non going concern walaupun memiliki masalah likuiditas, diantaranya seperti PT Maskapai Reasuransi Indonesia, PT Eka Sari Lorena Transport, PT Pelayaran Nelly Dwi Putri , dan lainnya. Perusahaan-perusahaan tersebut memiliki laporan auditor independen yang pada bagian opini audit maupun catatan atas laporan keuangannya mengungkapkan mengenai kondisi perusahaan yang mengalami masalah likuiditas akibat pandemi Covid-19, tetapi auditor menyimpulkan kondisi tersebut tidak berdampak signifikan sehingga menyatakan perusahaan tetap dapat memperoleh opini audit non going concern. Meskipun ada keraguan auditor, namun tingkat keraguan masih kecil sehingga tidak memerlukan modifikasi atas opini audit yang diberikan karena perusahaan telah mengemukakan rencana manajemen dengan efektif dan pengungkapan atas semua kondisi tersebut dalam laporan keuangannya. 
Beberapa kondisi tersebut tidak menunjukkan sepenuhnya perusahaan akan mendapatkan opini audit going concern, karena beberapa alternatif penyelesaian atas masalah likuiditas tersebut masih dapat dilakukan, seperti memperbaiki likuiditas perusahaan dengan memperoleh tambahan modal dari investor ataupun pinjaman dari kreditur, bahkan tidak menutup kemungkinan perusahaan dapat memperoleh laba dengan inovasi baru sebagai bentuk adaptasi menjaga eksistensi atau going concern perusahaan dalam ketidakpastian lingkungan, sehingga perusahaan pada akhirnya mampu menutupi defisiensi likuditas perusahaan. Oleh karena itu, variabel likuiditas menunjukkan hasil yang berpengaruh tidak signifikan terhadap penerimaan opini audit going concern.

\section{Pengaruh Solvabilitas Terhadap Opini Audit Going Concern}

Berbeda dengan likuiditas yang hanya mengukur kemampuan perusahaan melunasi kewajiban jangka pendek, solvabilitas mengukur kemampuan perusahaan dalam memenuhi semua kewajibannya baik jangka pendek maupun jangka panjang. Variabel solvabilitas dengan tingkat signifikansi hasil uji statistik secara parsial menunjukkan nilai signifikansi 0.011 , yang berarti lebih kecil dari 0.025 sehingga hipotesis $3\left(\mathrm{H}_{3}\right)$ diterima bahwa solvabilitas berpengaruh signifikan terhadap opini audit going concern.

Berdasarkan model regresi yang terbentuk dari hasil uji regresi logistik diketahui nilai koefisien untuk variabel solvabilitas yaitu -12.448 , yang artinya terdapat pengaruh negatif antara solvabilitas dengan opini audit going concern. Jika nilai solvabilitas perusahaan tinggi, artinya perusahaan memiliki kemampuan yang baik dalam memenuhi kewajiban jangka pendek maupun jangka panjangnya maka akan mengakibatkan probabilitas penerimaan opini audit going concern perusahaan akan semakin rendah.

Perusahaan dengan solvabilitas yang baik dianggap mampu mengatur penggunaan utang dari kreditur dengan baik untuk memaksimalkan nilai ekuitas perusahaan, sehingga perusahaan dapat mempertahankan kelangsungan hidupnya. Jika dikaitkan dengan teori stakeholder, perusahaan dengan kondisi solvabilitas yang baik tentunya akan mendapatkan dukungan dari para stakeholdernya, sehingga dengan kepercayaan yang baik keberlangsungan usaha perusahaan di masa yang akan datang juga semakin baik. Solvabilitas menjadi indikator penting untuk menilai perusahaan telah dikelola secara efektif dan efisien.

Oleh karena itu, sesuai dalam konsep teori atribusi maka auditor dapat menilai secara lebih detail terkait dengan kondisi solvabilitas suatu perusahaan untuk menentukan opini audit yang tepat sesuai dengan kondisi keuangannya. Auditor hendaknya dapat berperilaku konsisten dalam memberikan penilaian berupa opini audit, di mana perusahaan dengan kondisi solvabilitas yang rendah memiliki probabilitas tinggi untuk 


\section{DA}

Vol. 6, No. 1, Oktober 2021

mendapatkan opini audit going concern sedangkan perusahaan dengan solvabilitas yang tinggi memiliki probabilitas rendah untuk menerima opini audit going concern.

Kondisi solvabilitas yang baik adalah di mana perusahaan memiliki kemampuan yang baik dalam memenuhi seluruh kewajibannya, dengan perbandingan modal sendiri dengan modal pinjaman yang seimbang, yang artinya perusahaan tidak memiliki terlalu tinggi jumlah pinjaman ataupun terlalu rendah modal sendiri, karena pinjaman yang terlalu tinggi memiliki risiko yang tinggi pula terhadap masalah solvabilitas perusahaan. Meskipun dengan pinjaman tersebut juga memiliki peluang yang besar untuk perusahaan dapat memperoleh laba yang tinggi.

Keberlangsungan usaha menjadi hal yang dipertanyakan, ketika utang jangka panjang yang dimiliki tidak dapat dilunasi. Jika kondisi seperti ini terjadi, tentunya kepercayaan para stakeholders akan berkurang hingga perusahaan pada akhirnya dapat benar-benar dilikuidasi. Hal itu tentunya merugikan banyak pihak, terutama para investor dan kreditur. Manajemen dapat dinilai tidak optimal dalam mengelola dana secara efektif dan efisien sehingga kondisi tersebut mengakibatkan ketidakpastian atas kelangsungan usaha perusahaan. Jika saja manajer keuangan dapat memanfaatkan pinjaman tersebut secara efektif dan efisien, maka perusahaan akan tetap dapat going concern serta tidak merugikan pihak kreditur maupun investor. Hasil penelitian ini sejalan dengan hasil penelitian terdahulu seperti penelitian dari Wardani (2017), Anita (2017), Nugroho et al.,(2018), serta Rahman dan Ahmad (2018) yang membuktikan bahwa solvabilitas berpengaruh signifikan terhadap opini audit going concern. Penelitian dari Purba dan Nazir, (2019) serta Haryanto dan Sudarno (2019) juga menunjukkan hasil yang sama bahwa solvabilitas berpengaruh signifikan terhadap penerimaan opini audit going concern. Akan tetapi penelitian dari Tryansyah dan Khairunnisa (2019) serta Jalil (2019) menunjukkan hasil bahwa solvabilitas tidak berpengaruh signifikan terhadap opini audit going concern.

\section{SIMPULAN}

Berdasarkan hasil dan pembahasan terhadap pengujian statistik dengan menggunakan analisis regresi logistik biner, tentang pengaruh profitabilitas, likuiditas, dan solvabilitas terhadap opini audit going concern maka dapat disimpulkan hal-hal sebagai berikut:

1) Profitabilitas $\left(X_{1}\right)$ berpengaruh tidak signifikan terhadap opini audit going concern $(\mathrm{Y})$ pada perusahaan sektor jasa yang terdaftar di Bursa Efek Indonesia pada tahun 2015-2019. Hal tersebut dibuktikan, dengan nilai signifikansi hasil uji hipotesis parsial dengan analisis regresi logistik sebesar 0.807 yang lebih besar dari 0.025 dan nilai koefisien model regresi 0.130 yang artinya, semakin tinggi nilai profitabilitas 
perusahaan maka akan semakin tinggi juga probabilitas sebuah perusahaan menerima opini audit going concern.

2) Likuiditas $\left(\mathrm{X}_{2}\right)$ berpengaruh tidak signifikan terhadap opini audit going concern $(Y)$ pada perusahaan sektor jasa yang terdaftar di Bursa Efek Indonesia pada tahun 2015-2019. Hal tersebut dibuktikan, dengan nilai signifikansi hasil uji hipotesis parsial dengan analisis regresi logistik sebesar 0.214 yang lebih besar dari 0.025 dan nilai koefisien model regresi -15.446 yang artinya, semakin rendah nilai likuiditas sebuah perusahaan maka akan semakin tinggi peluang sebuah perusahaan menerima opini audit going concern.

3) Solvabilitas $\left(\mathrm{X}_{3}\right)$ berpengaruh signifikan terhadap opini audit going concern $(\mathrm{Y})$ pada perusahaan sektor jasa yang terdaftar di Bursa Efek Indonesia pada tahun 2015-2019. Hal tersebut dibuktikan, dengan nilai signifikansi hasil uji hipotesis parsial dengan analisis regresi logistik sebesar 0.011 yang lebih kecil dari 0.025 dan nilai koefisien model regresi -12.448 yang artinya, semakin rendah nilai solvabilitas perusahaan maka akan semakin tinggi peluang sebuah perusahaan untuk menerima opini audit going concern.

Berdasarkan pemaparan hasil dan pembahasan terdapat keterbatasan dalam penelitian ini, yaitu sebagai berikut:

1) Penelitian hanya terbatas menguji pada tiga faktor keuangan yang mempengaruhi pemberian opini audit going concern yaitu, profitabilitas, likuiditas, dan solvabilitas. Peneliti selanjutnya dapat menguji berbagai faktor lainnya yang juga mempengaruhi opini audit going concern seperti faktor non keuangan, yaitu mitigating evidence, disclosure, risiko, reputasi auditor, tenur auditor dan ukuran perusahaan, sehingga dapat diperoleh hasil yang semakin mencerminkan faktor apa saja yang paling mempengaruhi dalam pemberian opini audit going concern.

2) Metode pengukuran rasio profitabilitas, likuiditas, dan solvabilitas terbatas dan fokus hanya dengan masing-masing satu metode rasio yaitu ROE, Cash Ratio, dan DER. Peneliti selanjutnya, dapat menggunakan kombinasi pengukuran rasio keuangan yang berbeda untuk lebih memperkaya kajian tentang pengukuran faktor-faktor yang mempengaruhi pemberian opini audit going concern. Selain itu, dapat pula menggunakan metode analisis yang berbeda selain metode analisis rasio keuangan, yaitu metode analisis fluktuasi saldo dan financial distress model. 


\section{DAA}

Vol. 6, No. 1, Oktober 2021

\section{DAFTAR PUSTAKA}

Agoes, S. (2011). Auditing: Petunjuk Praktis Pemeriksaan Akuntan Oleh Akuntan Publik (Edisi 4 Bu). Penerbit Salemba Empat.

Aliah, M. (2015). Faktor keuangan dan non keuangan pada opini going concern. Universitas Muhammadiyah Surakarta.

Ambarwati, A. D., \& Suwarno, A. E. (2019). Pengaruh Pertumbuhan Perusahaan, Profitabilitas, Likuiditas, Leverage, dan Financial Distress Terhadap Opini Audit Going Concern (Studi Empiris pada .... http://eprints.ums.ac.id/id/eprint/78861

Anita, W. F. (2017). Analisis Faktor-Faktor Yang Mempengaruhi Opini Audit Going Concern Pada Perusahaan Manufaktur Yang Terdaftar Di Bursa Efek Indonesia. Jurnal Riset Keuangan Dan Akuntansi, 3(2), 87-108. https://doi.org/10.25134/jrka.v3i2.939

Aprilia, K. S. C. (2019). Pentinya Rasio Solvabilitas dalam Bisnis. Kompasiana.Com.

Arifah, D. A. (2012). Praktek Teori Agensi Pada Entitas Publik dan Non Publik. Prestasi, 9(1), 85-95.

Atikoh, S. (2017). Faktor Keuangan dan Non Keuangan dalam Memprediksi Pemberian Opini Audit.

Basri, F. (2019). Sektor Jasa Masih Jadi Pendorong Pertumbuhan Ekonomi Indonesia. Liputan6.Com.

Bayudi, N., \& Wirawati, N. gusti P. (2017). Faktor-Faktor Yang Memengaruhi Pemberian Opini Audit Going Concern. E-Jurnal Akuntansi, 19(1), 109136.

bps.go.id. (n.d.). Badan Pusat Statistik. Retrieved November 4, 2020, from https://www.bps.go.id/pressrelease/2020/02/05/1755/ekonomiindonesia-2019-tumbuh-5-02-persen.html

Gallizo, J. L., \& Saladrigues, R. (2016). An analysis of determinants of going concern audit opinion: Evidence from Spain stock exchange. Intangible Capital, 12(1), 1-16. https://doi.org/10.3926/ic.683

Ghozali, I. (2018). Aplikasi Analisis Multivariate Dengan Program IBM SPSS 25 (A. Tejokusumo (ed.); Edisi 9). Badan Penerbit Universitas Diponegoro.

Gregory, DS \& Bader, K. 2018. Logistic and Linear Regression Assumptions: Violation Recognition and Control. SESUG Paper 247 -2018. https://www.researchgate.net/publication/341354759_Logistic_and_Li near_Regression_Assumptions_Violation_Recognition_and_Controls

Haryanto, Y. A., \& Sudarno. (2019). Pengaruh Profitabilitas, Solvabilitas, Likuiditas, Dan Rasio Pasar Terhadap Opini Audit Going Concern Pada 
Perusahaan Manufaktur Di Bursa Efek Indonesia. Diponegoro Journal of Accounting, 8(4), 1-13.

Heze, E. (2018). Analisis Rasio Keuangan:Pengertian dan Rumus Rasio Kas (Cash Ratio). Sahamgain.Com.

IAPI, I. A. P. I. (2011). SA 341: Pertimbangan auditor atas kemampuan entitas dalam mempertahankan kelangsungan hidupnya (Issue 30).

Indonesia, I. A. P. (2012). SA 705.pdf(pp. 1-34).

Indrawati. (2011). Mengapa Memperhatikan Likuiditas Penting. Blog.StieMce.Ac.Id.

Institut Akuntan Publik Indonesia. (2012). SA 570.pdf(pp. 1-16).

Intan, N., \& Zuraya, N. (2019). BI: Perang Dagang Penyebab Utama Ekonomi Indonesia Melemah. Republika.Co.Id.

Jalil, M. (2019). Pengaruh Kondisi Keuangan dan Solvabilitas terhadap Opini Audit Going Concern (Studi Kasus pada perusahaan Manufaktur yang terdaftar di BEI). Jurnal Akuntnasi Dan Keuangan, 8(1), 52-62.

Junaidi dan Nurdiono. (2016). Kualitas Audit Perspektif Opini Going Concern (B. Hartadi (ed.)). CV Andi Offset.

Kasmir. (2019). Analisis Laporan Keuangan (Edisi Revi). Rajawali Pers.

Kurbani, A., Heryati, H., \& Rismansyah, R. (2019). Analisis Likuiditas Dan Profitabilitas Melalui Variabel Intervening Kualitas Audit Terhadap Opini Auidt Going Concern Pada Perusahaan Manufaktur Yang Terdaftar Di Bursa Efek Indonesia. Jurnal Manajemen Dan Bisnis Sriwijaya, 1入1), 1-16. https://doi.org/10.29259/jmbs.v17i1.8943

Kusuma, D. R. (2019). Perang dagang AS vs China, Apa dampaknya bagi Indonesia. Kumparan.Com.

Nugroho, L., Nurrohmah, S., \& Anasta, L. (2018). Faktor-Faktor Yang Mempengaruhi Opini Audit Going Concern. Jurnal SIKAP (Sistem Informasi, Keuangan, Auditing Dan Perpajakan), 2(2), 96. https://doi.org/10.32897/sikap.v2i2.79

Pradika, R. A. (2017). Pengaruh Profitabilitas, Likuiditas,Dan Ukuran Perusahaan Terhadap Going Concern Pada Perusahaan Manufaktur di Bei.

Purba, M. P. (2016). Asumsi Going Concern; Suatu Tinjauan terhadap Dampak Krisis Keuangan atas Opini Audit dan Laporan Keuangan (Edisi 2). Ekuilibria.

Purba, S. F., \& Nazir, N. (2019). Pengaruh Pertumbuhan Perusahaan, Rasio Keuangan, Dan Kualitas Auditor Terhadap Opini Audit Going Concern. $\begin{array}{llll}\text { Jurnal Akuntansi } & \text { Trisakti, }\end{array}$ https://doi.org/10.25105/jat.v5i2.5238 


\section{JAA}

Vol. 6, No. 1, Oktober 2021

Rahman, M. A., \& Ahmad, H. (2018). Pengaruh Likuiditas, Profitabilitas, dan Solvabilitas Terhadap Opini Audit Going Concern. Jurnal Akuntansi, 1(2), 44-55.

Ramadhan, A. (2020). Likuiditas sebagai Navigator Masa Depan Perusahaan. Finata.Id.

Rohim, I. (2018). Rasio Profitabilitas. Dconsultingbusinessconsultant.Com.

Tryansyah, G. I., \& Khairunnisa. (2019). Pengaruh Reputasi Auditor , Profitabilitas, Leverage, dan Pertumbuhan Perusahaan Terhadap Penerimaan Opini Audit Going Concern ( Study of Mining Sector Companies Listed in Indonesia Stock Exchange in Period 2013-. EProceeding of Management, 6(2), 3572-3579.

Wardani, S. (2017). Faktor-Faktor yang Mempengaruhi Opini Audit Going Concern. 9(5), 1-14.

Wibisono, A. (2019). Pengaruh Likuiditas, Profitabilitas dan Solvabilitas Terhadap Pemberian Opini Audit Going Concern (Studi Pada Perusahaan Grup Bakrie Di BEI ).

Yaqin, M. A., \& Sari, M. M. R. (2015). Pengaruh Faktor Keuangan Dan Non Keuangan Pada Opini Audit Going Concern. E-Jurnal Akuntansi Universitas Udayana, 2, 500-514. 